\title{
Mengukur Minat Studi Siswa SMA dan SMK Di Kota Bogor Pada Program Studi Kewirausahaan
}

Sulistiono ${ }^{1}$ Yulia Nurendah² Mumuh Mulyana²

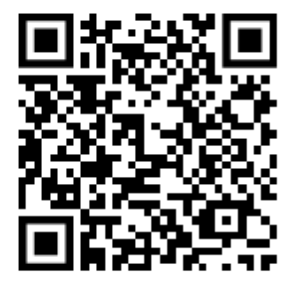

\section{Abstrak}

Data empiris menunjukkan kewirausahaan berimplikasi positif terhadap pertumbuhan perekonomian Indonesia. Kewirausahaan memiliki peranan penting untuk menjadikan masyarakat lebih kreatif dan mandiri. Ketersediaan SDM menjadi penting dalam perekonomian. Penelitian ini memiliki tujuan untuk mengetahui dan menganalisis: 1) minat siswa SMA dan SMK di Kota Bogor untuk melanjutkan studi, 2) besarnya minat siswa SMA dan SMK di Kota Bogor untuk melanjutkan studi, 3) jenjang pendidikan yang dipilih siswa SMA dan SMK di Kota Bogor, 4) pilihan jurusan untuk melanjutkan pendidikan lanjut, 5) besar keyakinan pilihan program studi, 6) pengetahuan siswa SMA dan SMK terhadap Program Studi Kewirausahaan, 7) ketertarikan Siswa SMA dan SMK di Kota Bogor untuk mendaftar pada Program Studi Kewirausahaan. Hasil penelitian menunjukkan: Minat studi lanjut siswa SMA/SMK Kota Bogor setelah lulus sekolah berada pada level sangat kuat, Mayoritas siswa SMA/SMK Kota Bogor memiliki minat sangat tinggi untuk melanjutkan studi, Jenjang pendidikan yang dipilih siswa siswi SMA/SMK di Kota Bogor setelah lulus adalah jenjang sarjana $(84,28 \%)$ dan jenjang pendidikan diploma tiga $(10,84 \%)$, Jurusan/program studi yang dipilih untuk melanjutkan studi terbesar adalah jurusan ekonomi dan manajemen, Siswa yang merasa yakin dan sangat yakin terhadap pilihan program studi/jurusannya ada sebanyak $83,79 \%$ dan 45,80\% Responden siswa SMA/SMK di Kota Bogor menyatakan pernah mendengar/tahu tentang prodi kewirausahaan, artinya prodi kewirausahaan sudah cukup dikenal di kalangan siswa SMA / SMK di Kota Bogor, serta Responden siswa SMA/SMK di Kota Bogor yang menyatakan berminat untuk mendaftar pada prodi kewirausahaan hanya sebesar $15,23 \%$ artinya minat mendaftar pada prodi kewirausahaan masih relative rendah.

Kata Kunci: minat studi, kewirausahaan, program studi, siswa SMA dan SMK

\section{PENDAHULUAN}

Wacana mengenai wirausaha sempat menggeliat pada tahun 90an dengan usungan program pemerintah Gerakan Nasional Memasyarakatkan Kewirausahaan (GMNK). Setelah itu, pemerintah mulai giat juga mendorong pertumbuhan kewirausahaan khususnya melalui program-program yang dibuat oleh kementrian Koperasi dan UKM. Wirausaha dipandang sebagai salah satu solusi untuk menekan tingkat pengangguran.
Program Studi Manajemen Pemasaran Sekolah Tinggi IImu Ekonomi Kesatuan, Jalan Ranggagading No. 1 Bogor Indonesia

EMail

angga.sulistiono@stiekesatu an.ac.id
Submitted: Februari 2019

Accepted : Juli 2019

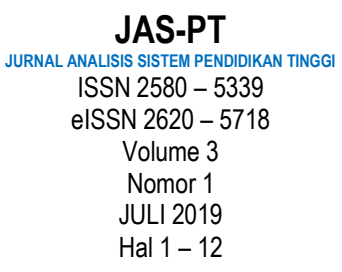

FORUM DOSEN INDONESIA 
Selain bisa menciptakan pekerjaan bagi diri sendiri, wirausaha juga dapat membuka kesempatan kerja bagi orang lain.

Namun hingga saat ini, Indonesia memiliki jumlah wirausaha yang lebih sedikit dibandingkan jika dibandingkan negara-negara seperti Amerika, Singapura, Malaysia, Korea Selatan, dan Thailand. Perekonomian di negara-negara tersebut mendukung tumbuhnya wirausaha ini. Menjadi Entrepreneur merupakan impian bagi sebagian besar dari penduduk di sana, sebagian beranggapan menjadi wirausaha adalah jalan menuju kekayaan.

Pada Tahun 2013 jumlah wirausaha di Indonesia hanya 570.339 orang atau 0,24\% dari jumlah penduduk yang sebanyak 237,64 juta orang. Padahal untuk jadi bangsa maju, dibutuhkan wirausaha minimal $2 \%$ dari jumlah penduduk (www.detikfinance.com). Pada tahun yang sama, pemerintah mulai terus meningkatkan dan mengembangkan program wirausaha produktif untuk melatih pengangguran mulai dari lulusan SD sampai sarjana. Sebab untuk mencapai jumlah ideal, Indonesia masih membutuh tambahan sekitar 4,18 juta wirausaha, sehingga target ideal jumlah wirausaha sebanyak 4,75 juta wirausaha dapat tercapai dalam waktu tidak terlalu lama.

Sasaran kelompok masyarakat yang menjadi calon grup kewirausahaan adalah penganggur/masyarakat miskin di pedesaan, penganggur terdidik di perkotaan, calon TKI, TKI dan formal dan transmigran/calon transmigran. Di tingkat nasional, pada Tahun 2013 pemerintah telah menyepakati naskah Kesepakatan Bersama 5 Kementerian untuk bersinergi dalam perluasan kesempatan kerja dan peningkatan kesejahteraan tenaga kerja melalui kewirausahaan. Kesepakatan lintas kementerian ini melibatkan Kementerian Tenaga Kerja dan Transmigrasi, Kementerian Perindustrian, Kementerian Kelautan dan Perikanan, Kementerian Koperasi dan UKM, dan Kementerian Pemuda dan Olahraga.

Peran kewirausahaan sangat diperlukan untuk pertumbuhan perekonomian di Indonesia. Terdapat beberapa alasan mengapa kewirausahaan merupakan faktor yang bisa mendorong pertumbuhan ekonomi di Indonesia, yaitu sebagai berikut :

1. Dengan adanya kewirausahaan masyarakat dapat mempunyai kemampuan untuk menciptakan dan menyediakan produk yang bernilai tambah atau inovasiinovasi yang baru sehingga dapat menjadikan masyarakat lebih kreatif dalam menyampaikan ide-ide dan kreasinya, mereka bisa menciptakan barang yang dirasa perlu dan penting untuk kesejahteraan masyarakat itu sendiri sehingga tidak perlu menimpor dari luar negeri.

2. Masyarakat tidak tergantung dengan pemerintah seperti tenaga kerja negeri (PNS) yang masih digaji oleh pemerintah, bahkan seorang wirausaha akan mendatangkan omset yang akan di berikan ke negara melalui pajak. Secara tidak langsung kesejahteraan ekonomi masyarakat bisa stabil.

3. Menarik invesrtor asing untuk berinverstasi atau menanamkan modalnya di Indonesia. Dengan adanya investor asing seperti itu maka akan dapat menambah devisa negara. Selain itu wirausaha dapat mendorong meningkatnya sektor pariwisata di Indonesia. Contohnya: Seorang wirausaha membuka usaha pembangunan hotel di dekat pantai Lovina, Daerah Buleleng, Bali. Dengan adanya hotel di depan pantai Lovina maka akan mengundang para turis asing untuk mengunjungi pantai Lovina selain karena devisa negara akan bertambah, si wirausahawan akan membayar pajak dari jumlah pendapatan yang dia peroleh dari usahanya membangun hotel 
Pada kurun waktu belakangan ini, pembahasan mengenai kewirausahaan makin marak terutama karena banyak wirausaha-wirausaha sukses ikut berusaha untuk berpartisipasi dalam bentuk pendidikan maupun mentoring langsung ke calon wirausaha. Peran media dan lembaga-lembaga terkait pun tak kalah penting. Kerjasama media dalam kegiatan-kegiatan penghargaan, ekspo, pameran bagi wirausaha membuat topik ini menjadi selalu hangat sepanjang tahun. Perusahaan Konsultan Manajemen sekelas Earns \& Young (EY) misalnya setiap tahun selalu memberikan penghargaan EY Entrepreneurs of The Year kepada wirausaha yang dinilai berhasil dalam bidangnya. Ditambah lagi dengan beragam penghargaan lain yang diberikan baik oleh pemerintah secara langsung memberikan daya ungkit yang terus mengangkat kemajuan kewirausahaan di Indonesia

Namun harus diingat, pertumbuhan jumlah wirausahawan harus didukung oleh lembaga pendidikan, termasuk perguruan tinggi. Pendidikan penting untuk memberi modal dasar bagi para wirausahawan. Melalui jalur pendidikan dapat mengubah pola pikir seseorang untuk menjadikan wirausahawan yang bekerja dengan menggunakan ide dan kreativitas.

Peran perguruan tinggi, dalam hal ini dapat memotivasi para sarjananya menjadi young entrepreneurs, yang merupakan bagian dari salah satu faktor pendorong pertumbuhan kewirausahaan. Siklus yang kemudian terjadi adalah dengan meningkatnya wirausahawan dari kalangan sarjana akan mengurangi pengangguran, serta menambah jumlah lapangan pekerjaan.

Di Bogor terdapat banyak perguruan tinggi yang berkompetisi dalam bidang pendidikan Namun, tidak dipungkiri, sebagian perguruan tinggi memiliki program studi atau jurusan yang sudah tidak diminati lagi. Banyak faktor yang menyebabkan hal tersebut. Untuk mengantisipasi, perubahan minat calon mahasiswa terhadap program studi tertentu, dibutuhkan suatu penelaahan dan penelitian yang mendalam tentang berbagai hal yang menjadi penyebabnya.

Untuk itu, penelitian berjudul "Mengukur Minat Studi Siswa SMA dan SMK di Kota Bogor Pada Program Studi Kewirausahaan", ini dilakukan sebagai upaya menjawab fenomena dimaksud.

Penelitian ini memiliki tujuan untuk mengetahui dan menganalisis:

1. Untuk mengetahui minat siswa SMA dan SMK di Kota Bogor untuk melanjutkan studi.

2. Untuk mengetahui besarnya minat siswa SMA dan SMK di Kota Bogor untuk melanjutkan studi

3. Untuk mengetahui jenjang pendidikan apa yang dipilih siswa SMA dan SMK di Kota Bogor.

4. Untuk mengetahui pilihan jurusan untuk melanjutkan pendidikan lanjut

5. Untuk mengehui seberapa besar keyakinan pilihan program studi

6. Untuk mengetahui pengetahuan siswa SMA dan SMK terhadap Program Studi Kewirausahaan

7. Untuk mengetahui ketertarikan Siswa SMA dan SMK di Kota Bogor untuk mendaftar pada Program Studi Kewirausahaan

JAS-PT

JURNAL ANALISIS SISTEM PENDIDIKAN TINGGI ISSN $2580-5339$ elSSN $2620-5718$

Volume 3

Nomor 1

JULI 2019

Hal $1-12$

FORUM DOSEN INDONESIA 


\section{TINJAUAN PUSTAKA}

Kewirausahaan adalah suatu proses penerapan kreativitas dan inovasi dalam memecahkan persoalan dan menemukan peluang untuk memperbaiki kehidupan. (Zimmerer, 1996).

Terdapat beberapa alasan mengapa dengan semakin banyak wirausahawan disuatu negara akan meningkatkan daya saing negara tersebut, yaitu sebagai berikut :

1. Sebuah negara yang memiliki wirausahawan banyak tentunya akan mendapatkan penghasilan yang besar dari sektor pajak, atas kegiatan ekonomi yang mereka lakukan

2. Dengan semakin banyak penduduk menjadi wirausaha, maka ekonomi mereka akan mandiri.

3. Ditinjau dari segi GNP (Gross National Product), akan meningkatkan GNP

Indonesia saat ini membutuhkan para wirausaha muda untuk dapat mendukung pertumbuhan ekonomi negara. Jumlah wirausaha di Indonesia baru mencapai 0,24 persen dari jumlah penduduk Indonesia yang mencapai 240 juta. Jumlah itu lebih rendah dibandingkan dengan wirausaha di beberapa negara luar yang tingkat pertumbuhan ekonominya tinggi, seperti Amerika Serikat yang mencapai 11\%, Singapura 7\%, dan Malaysia $5 \%$.

Dengan melihat perbandingan jumlah wirausaha di negara maju tersebut, wajar jika pertumbuhan perekonomian di Indonesia masih lambat, meskipun saat ini Indonesia adalah negara dengan tingkat pertumbuhan stabil. Oleh karena itu, pemerintah harus mengembangkan sektor kewirausahaan dan meningkatkan jumlah wirausahawan agar dapat berperan dalam mendukung ekonomi negara.

Tidak ada satu pun negara maju tanpa ditopang pertumbuhan entrepreneur. Indonesia harus memperbesar jumlah wirausahawan minimal dua persen dari jumlah penduduk atau sekitar empat juta orang. Peran Pemerintah, baik pusat maupun daerah dalam menciptakan wirausahawan muda, masih sangat kecil bila dibandingkan dengan jumlah pemuda saat ini.Sudah seharusnya pemerintah berorientasi pada pembangunan ekonomi berbasis penciptaan wirausahawan-wirausahawan baru dari kalangan pemuda.

Program kegiatan di berbagai sektor dan urusan pemerintah perlu diorientasikan agar terciptanya kesempatan bagi pemuda untuk berwirausaha.Sehingga pemuda Indonesia tidak melulu harus mencari kerja, selepas mengenyam pendidikan. Dengan terbukanya kesempatan berwirausaha bagi pemuda, maka sikap, mental dan cara berpikir mereka akan berubah. Perlu juga inisiatif pemerintah untuk mendirikan lembaga pembiayaan dan bank untuk pemuda atau lembaga keuangan nonperbankan yang khusus untuk melayani nasabah dari kalangan pemuda atau wirausahawan baru. Cara lain yang bisa dilakukan pemerintah adalah mendorong agar lembaga keuangan dapat memberikan porsi yang seluas-luasnya untuk mengucurkan kredit bagi wirausahawan muda dengan persyaratan yang lebih mudah.

JAS-PT

JURNAL ANALISIS SISTEM PENDIDIKAN TINGG ISSN $2580-5339$ eISSN $2620-5718$

Volume 3

Nomor 1

JULI 2019

Hal $1-12$

FORUM DOSEN INDONESIA
Harus ada political and good will yang diaplikasikan dalam kebijakan anggaran dalam mendukung penciptaan wirausahawan muda sehingga impian seorang Ciputra untuk melihat ada empat juta pemuda entrepreneur dalam 25 tahun ke depan dapat terwujud. Sebagaimana Undang-Undang Kepemudaan menurut Hermawan Kartawijaya, pendiri MarkPlus Institute of Marketing, mengajak Pemuda Indonesia untuk jadi Moral Force, Social Control dan Agent of Change. Karena itu, mereka juga diharapkan jadi Leader, Entrepreneur dan Pioneer. 
Indonesia masih kekurangan pengusaha-pengusaha baru.Indonesia masih defisit pengusaha, sehingga perlu ditumbuhkan pengusaha-pengusaha baru.Saat ini jumlah pengusaha Indonesia masih berada di angka 1\%.Sedangkan jumlah pengusaha di negara maju setidaknya berada di angka $5 \%$ dari total penduduknya. Untuk itu dibutuhkan peran konkret pemerintah melalui penciptaan program pendidikan kewirausahaan bagi pemuda untuk memberikan kesempatan belajar kepada mereka agar memperoleh pengetahuan, keterampilan, dan menumbuhkembangkan jiwa kewirausahaan.Namun, perlu disadari pula bahwa pemerintah agaknya tidak mampu melakukan hal itu sendiri, mengingat segala keterbatasan pendanaan dan infrastruktur pendukung lainnya. Karena itu, dibutuhkan kontribusi dan peran pihak-pihak lain untuk mewujudkan hal itu. Selain itu, perlu adanya penumbuhan niat bagi kalangan anak muda untuk mau menjadi pengusaha atau enterpreneur.

Minat adalah kecenderungan tingkah laku umum seseorang untuk tertarik kepada sekelompok hal tertentu (Guilford dalam Munandir, 1996:146). Lester dan Alice Crow (dalam The Liang Gie, 1995:129-132), menekankan betapa pentingnya minat untuk mencapai sukses dalam hidup seseorang dan dalam segala hal. Dikatakannya: Suatu minat dalam belajar merupakan suatu kewajiban yang menyertai anda ke kelas dan menemani anda selama setiap tugas studi, dengan demikian memungkinkan anda berhasil dalam kegiatan studi.

Guilford (dalam Munandir, 1996:147-148), menyatakan bahwa jenis minat dibedakan atas ketertarikan orang terhadap bidang-bidang pekerjaan dapat dibagi menjadi tiga yaitu minat profesional, minat komersial, dan minat kegiatan fisik.

Minat berhubungan dengan dorongan, motif-motif dan responrespon manusia. Ada 3 faktor yang mempengaruhi minat yaitu faktor dorongan atau keinginan dari dalam, faktor motif sosial, dan faktor emosional (Viviepermata, diunduh 14/03/2010, http://vivipermata.blog friendster.com2008/08/28/)

Walgito (2002: 171-174) berpendapat bahwa mengenai motif ini ada beberapa teori yang diajukan yang memberikan gambaran tentang seberapa jauh peranan dari stimulus internal dan eksternal. Teori-teori tersebut adalah (1) teori insting (instinck theory); (2) teori dorongan (drive theory); (3) teori gejolak (arousal theory); (4) teori insentif (incentive theory).

Menurut The Liang Gie (1995:28-29), minat studi merupakan salah satu unsur sangat penting dari sikap akademik mahasiswa dalam kaitannya dengan penyelenggaraan pendidikan di perguruan tinggi. Minat yang besar terhadap kegiatan pikiran untuk menggali keterangan dan mencapai pemahaman tentang segenap cabang ilmu dalam bidang studinya adalah bagian dari sikap akademik mahasiswa Indonesia.

Keputusan untuk melanjutkan studi ke Perguruan Tinggi merupakan pilihan yang baik, namun tidak mudah untuk memilih selepas SLTA. Banyak lulusan SLTA yang tidak tahu ingin ke mana. Seseorang yang memasuki perguruan tinggi haruslah benar-benar telah menguasai mata pelajaran yang didapat dari sekolah menengah. Sebab jika tidak, pasti ia akan mengalami kesulitan belajar. Bahkan dapat dikatakan kesulitan ganda karena disamping ia harus mempelajari kembali bahan-bahan di sekolah menengah, ia juga harus cepat mencerna bahan-bahan kuliah yang biasanya diberikan dalam kecepatan yang relatif tinggi.

\footnotetext{
JAS-PT

JURNAL ANALISIS SISTEM PENDIDIKAN TINGGI ISSN $2580-5339$ eISSN $2620-5718$ Volume 3 Nomor 1 JULI 2019 Hal $1-12$ 


\section{METODOLOGI PENELITIAN}

Penelitian ini dilaksanakan pada beberapa Sekolah di Kota Bogor baik SMA maupun SMK. Waktu yang dibutuhkan untuk melaksanakan penelitian ini adalah selama 5 (lima) bulan, mulai Juli s/d November 2019. Desain Penelitian yang digunakan dalam penelitian ini adalah deskriptif. Populasi penelitian ini adalah seluruh siswa Kelas 3 pada SMA dan SMK di Kota Bogor. Sampel penelitian ditetapkan dengan metode convenience sampling. Metode analisis data penelitian ini adalah Analisis Deskriptif Distribusi Frekuensi.

\section{HASIL DAN PEMBAHASAN}

\section{Minat Studi Lanjut Siswa SMA/SMK Kota Bogor}

Berdasarkan hasil survey diperoleh hasil seperti tertera pada Gambar 1.

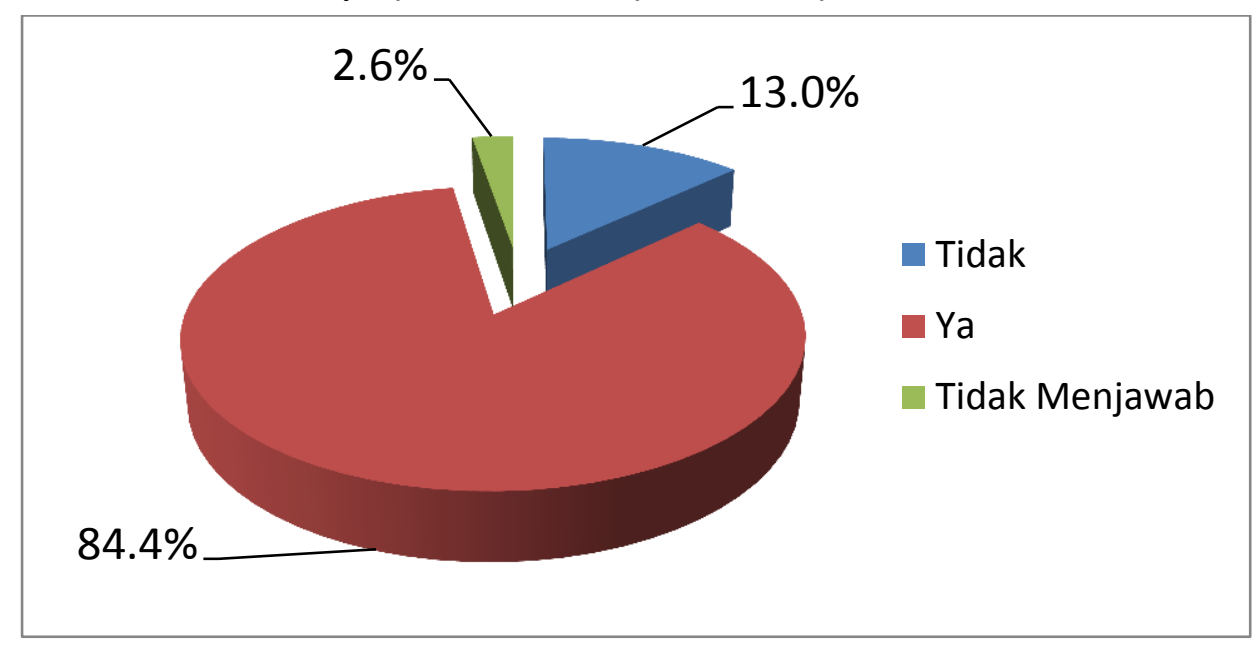

Gambar 1. Minat Studi Lanjut Lulus SMA/SMK

Hasil olah data minat studi lanjut siswa SMA/SMK di Kota Bogor menunjukan bahwa $84,4 \%$ memiliki minat untuk melanjutkan studi setelah lulus, $13,0 \%$ menyatakan tidak berminat melanjutkan studi dan sisanya 2,6\% tidak memberikan jawaban. Jika dilihat berdasarkan frekuensi menjawab nampak bahwa siswa yang memiliki minat melanjutkan pendidikan setelah lulus SMA/SMK menempati rangking tertinggi yaitu sebesar 864 orang. Dengan demikian dapat dikatakan bahwa kriteria interpretasi skor atas minat studi lanjut siswa SMA/SMK di Kota Bogor berada di kisaran 81\% - 100\% yang berarti sangat kuat.

\section{Tingkat Minat Studi Lanjut Siswa SMA/SMK Kota Bogor}

Hasil olah data menunjukkan bahwa tinggi/besarnya minat studi lanjut siswa SMA/SMK Kota Bogor adalah 51,5\% memiliki minat untuk melanjutkan studi sangat tinggi, 32,5\% memiliki minat tinggi/besar, $12,4 \%$ biasa saja dan $3,6 \%$ sisanya tidak memberikan jawaban. Berdasarkan frekuensi menjawab terlihat bahwa tinggi/besarnya minat studi

JAS-PT

JURNAL ANALISIS SISTEM PENDIDIKAN TINGGI

ISSN $2580-5339$ eISSN $2620-5718$

Volume 3

Nomor 1

JULI 2019

Hal $1-12$ lanjut siswa SMA/SMK Kota Bogor setelah lulus didominasi oleh jawaban minat studi lanjut yang sangat tinggi/besar (527 siswa). Dengan demikian maka hasil olah data tersebut menunjukan bahwa kriteria interpretasi skor atas tinggi/besar minat studi lanjut siswa SMA/SMK di Kota Bogor berada di kisaran tinggi/besar sampai dengan sangat tinggi/besar sebesar $84 \%$ yang berarti sangat kuat. 


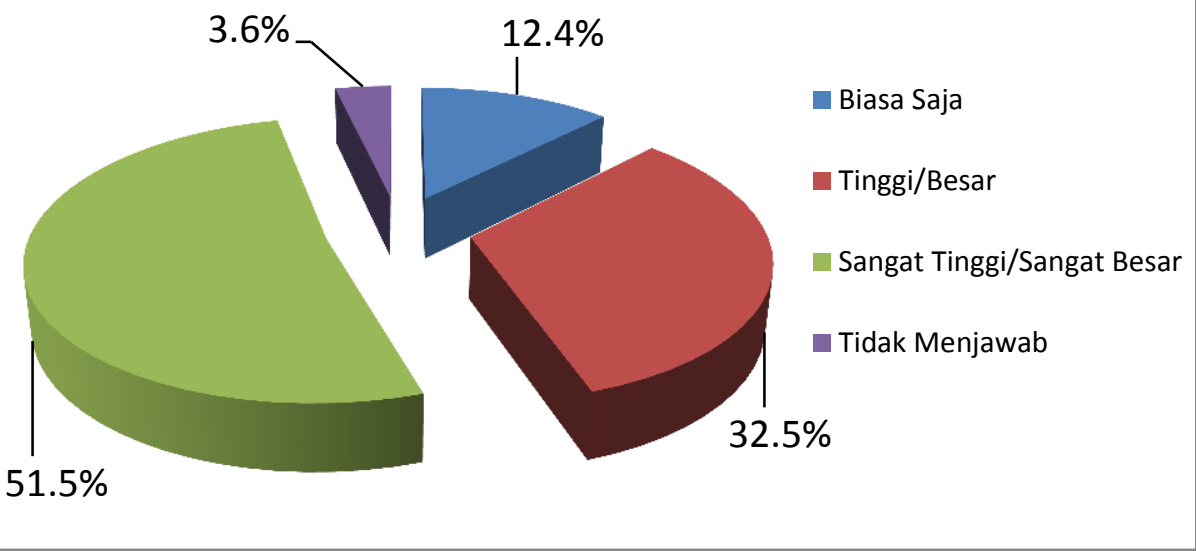

Gambar 2 Tinggi/Besarnya Minat Studi Lanjut Lulus SMA/SMK Kota Bogor

\section{Jenjang Studi Lanjut Pilihan Siswa SMA/SMK Kota Bogor}

Gambar 3 menampilkan data jenjang studi lanjut pilihan Siswa SMA/SMK Kota Bogor (1024 responden)

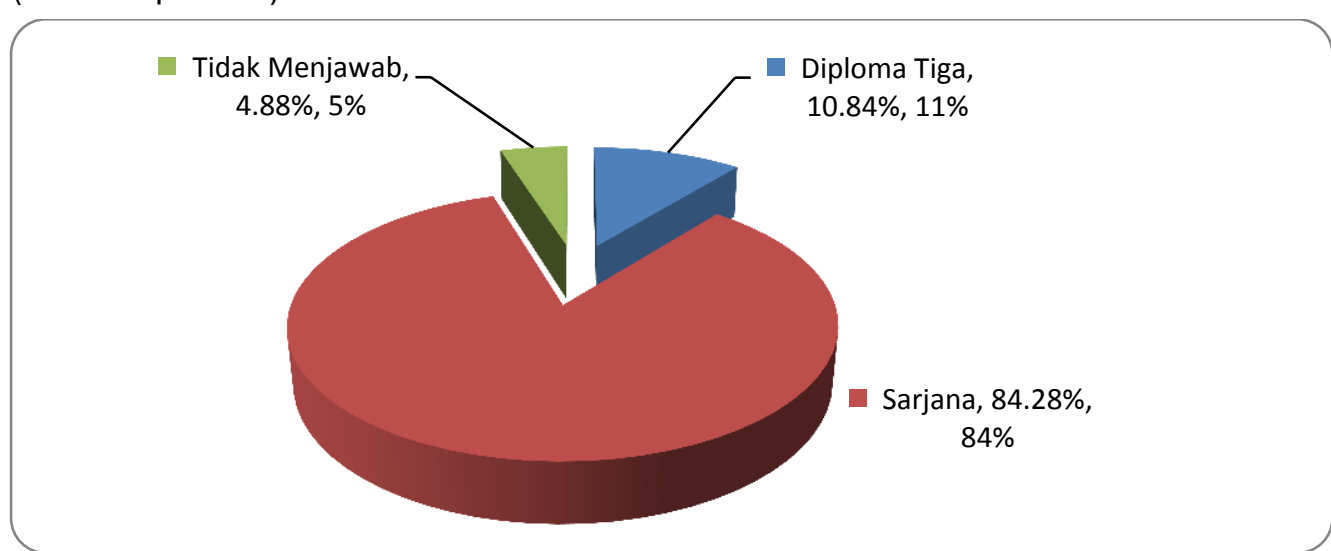

Gambar 3. Jenjang Pendidikan Pilihan Siswa SMA/SMK Kota Bogor

Hasil olah data menunjukan bahwa jenjang pendidikan dipilih untuk melanjutkan studi siswa SMA/SMK setelah lulus pada siswa siswi SMA/SMK di Kota Bogor menunjukan $84,28 \%$ memilih jenjang sarjana (S1), 10,84\% memilih jenjang pendidikan diploma tiga, dan $4,88 \%$ sisanya tidak memberikan jawaban. Sedangkan jika dilihat berdasarkan frekuensi jawaban responden maka terlihat bahwa jumlah siswa yang memilih program sarjana adalah yang paling tinggi yaitu sebanyak 863 orang, program diploma tiga 111 orang dan hanya 50 orang yang tidak memberikan jawaban. Dengan demikian dapat dikatakan bahwa kriteria interpretasi skor atas jenjang pendidikan dipilih untuk melanjutkan studi siswa SMA/SMK di Kota Bogor padajenjang sarjana penuh (S1) adalah sangat kuat.

\section{Jurusan Studi Lanjut Pilihan Siswa SMA/SMK Kota Bogor}

Hasil olah data menunjukan bahwa jurusan/program studi yang dipilih untuk melanjutkan studi terbesr adalah pada jurusan ekonomi dan manajemen dengan prosentase sebesar $43,4 \%$ atau sebanyak 444 orang, diposisi kedua ditempati oleh program studi teknik yakni sebesar $19,1 \%$ atau 196 orang, posisi terrendah ditempati oleh program studi peternakan yang hanya sebesar $1,5 \%$ atau 15 dari 1024 orang yang disurvey. Dengan demikian dapat dikatakan bahwa program studi ekonomi dan

JAS-PT

URNAL ANALSIS SISTEM PENDIDIKAN TINGGI ISSN $2580-5339$ eISSN $2620-5718$

Volume 3

Nomor 1

JULI 2019

Hal 1 - 12

FORUM DOSEN INDONESIA 
manajemen masih merupakan program studi favorit diantara delapan program studi yang ditawarkan.

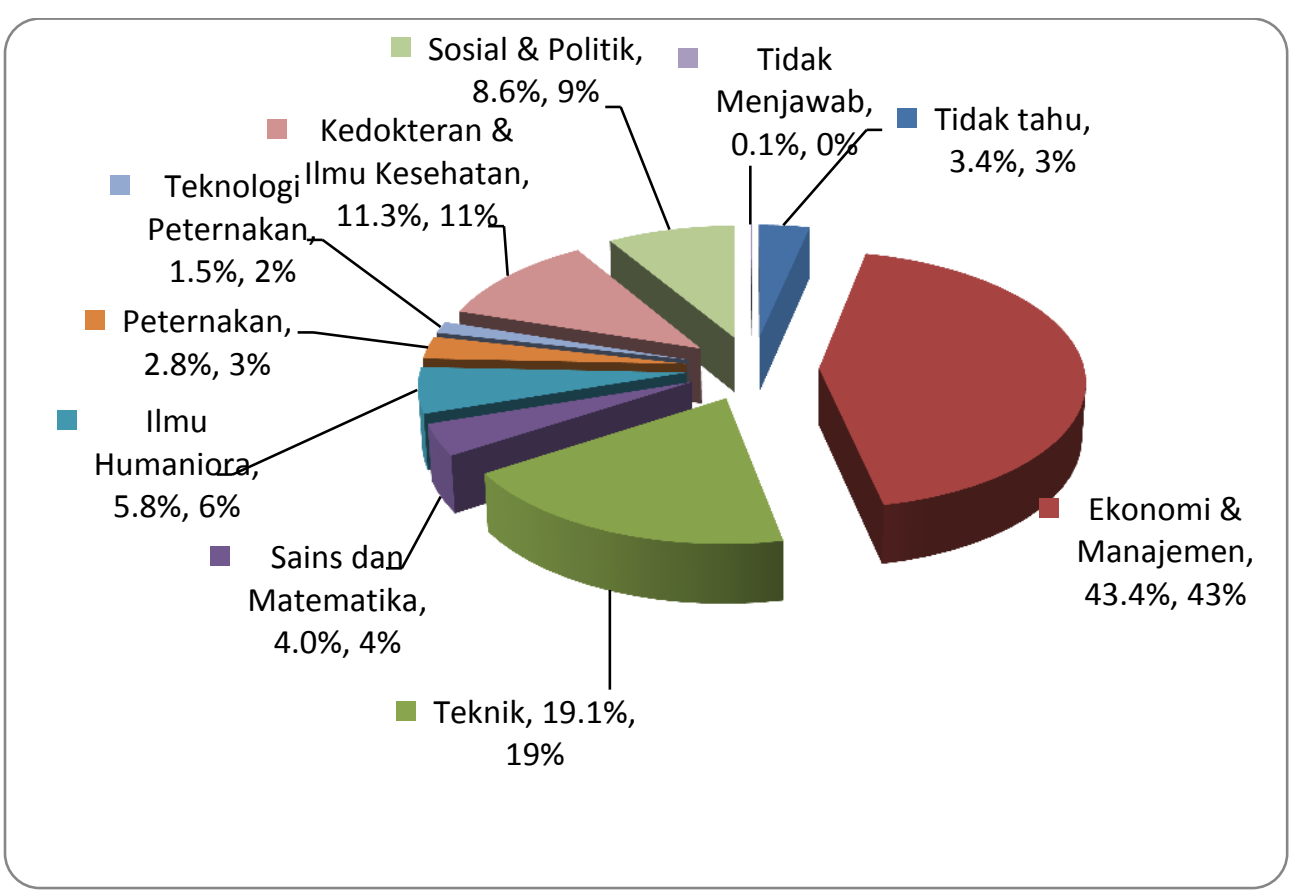

Gambar 4. Jurusan Studi Lanjut Pilihan Siswa SMA/SMK Kota Bogor

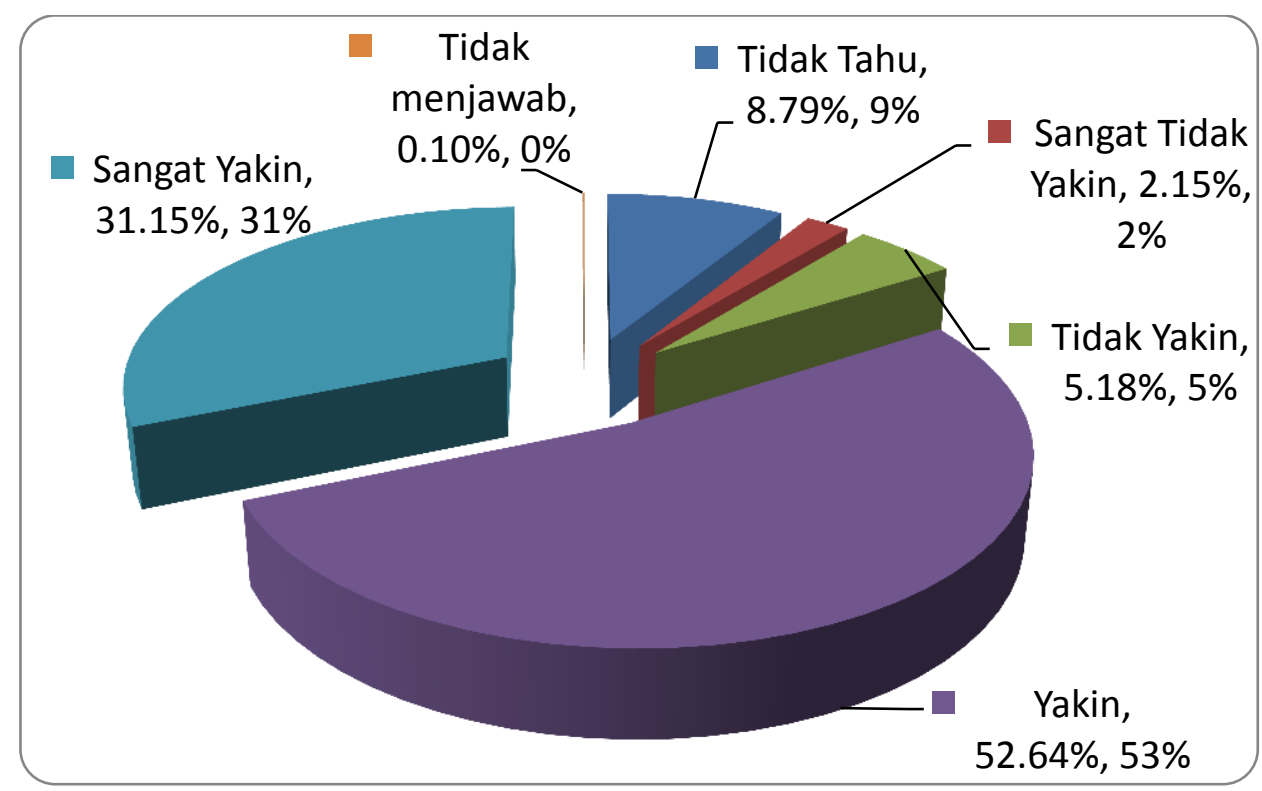

Gambar 5. Keyakinan Pilihan Program Studi

JAS-PT

JURNAL ANALISIS SISTEM PENDIDIKAN TINGGI

ISSN $2580-5339$

eISSN $2620-5718$

Volume 3

Nomor 1

JULI 2019

Hal $1-12$

FORUM DOSEN INDONESIA
Pilihan jurusan atau program studi tersebut masih harus disertai dengan tingkat keyakinan siswa dalam memilihnya. Hasil olah data berupa grafik dan table diatas menunjukkan bahwa siswa yang merasa sangat yakin dengan pilihannya ada sebanyak $31,15 \%$, siswa yang menjawab yakin ada sebanyak $52,64 \%$, dengan demikian dapat dinyatakan bahwa siswa yang yakin dan sangat yakin terhadap pilihan program studi/jurusannya ada sebanyak $83,79 \%$ yang artinya bahwa kriteria interpretasi skor sangat kuat. 

Kewirausahaan

Tingginya minat studi lanjut Siswa SMA/SMK Kota Bogor ke Jurusan Ekonomi dan Manajemen, tidak serta merta menggambarkan tingginya minat mereka ke program studi Kewirausahaan.

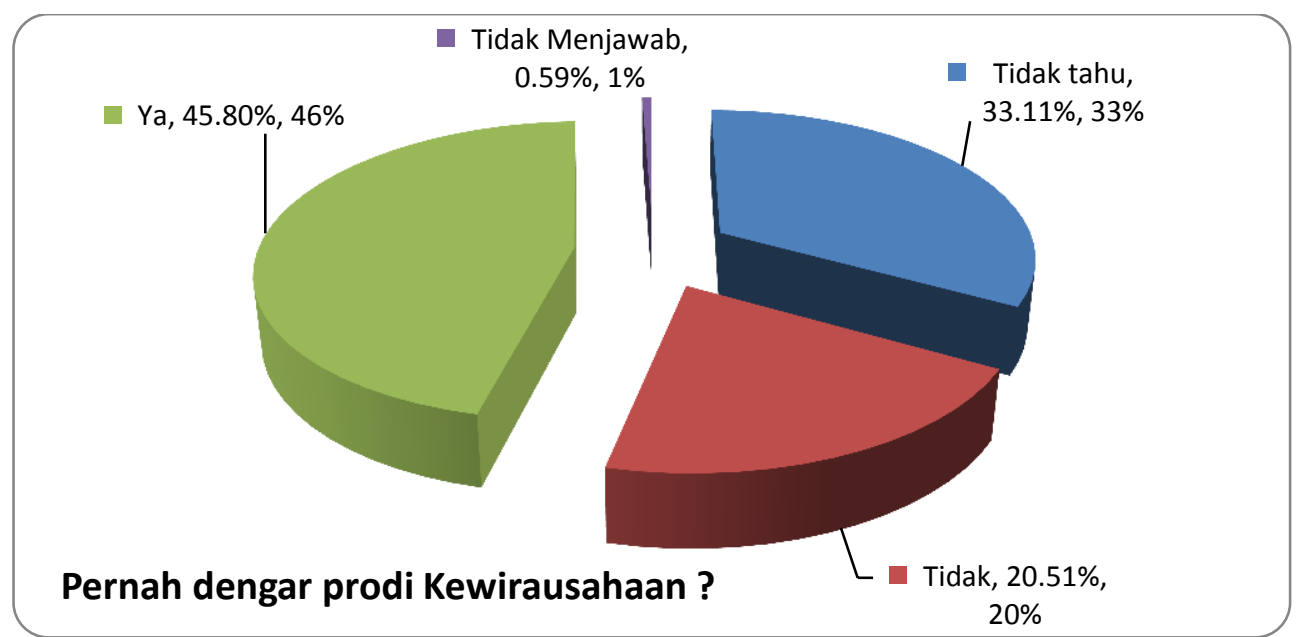

Gambar 6. Tingkat Pengetahuan Siswa tentang Prodi Kewirausahaan

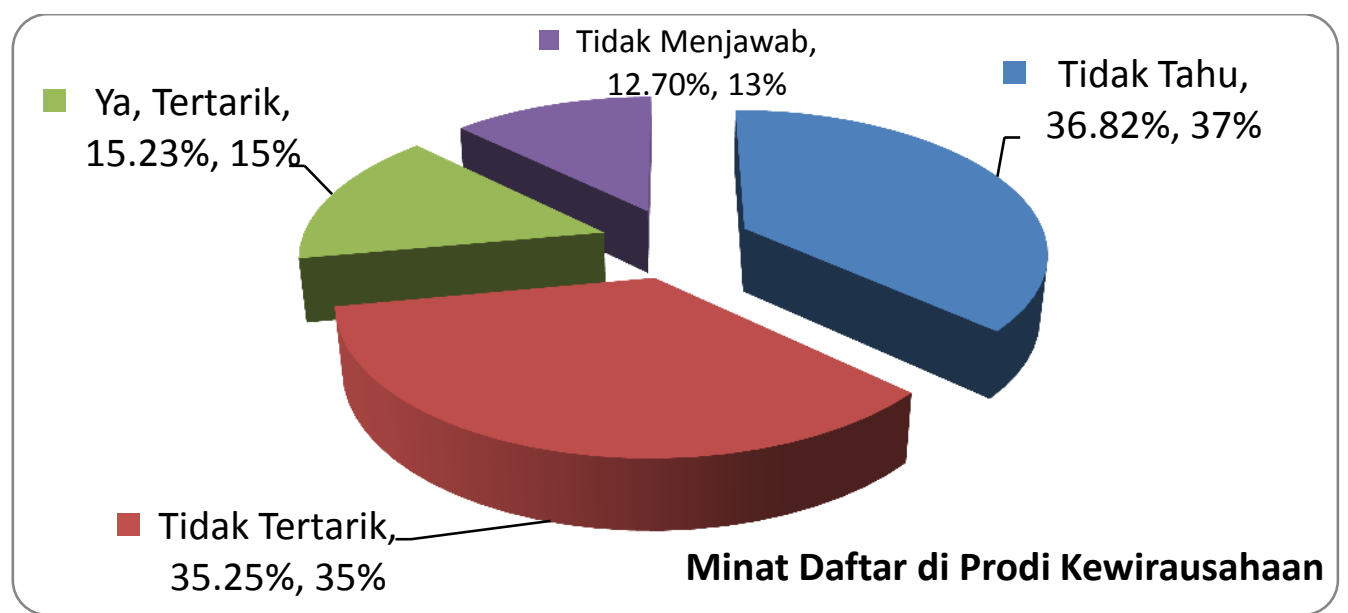

Gambar 7. Minat Siswa SMA/SMK Kota Bogor mendaftar pada Prodi Kewirausahaan

Tabel dan grafik hasil olah data di atas menunjukan bahwa responden yang terdiri dari 1024 orang siswa SMA/SMK di Kota Bogor yang menyatakan pernah mendengar /tahu tentang prodi kewirausahaan adalah sebesar $45,80 \%$ artinya prodi kewirausahaan sudah cukup dikenal di kalangan siswa SMA / SMk di Kota Bogor. Hanya sebesar $15,23 \%$ (masih relatif rendah) yang menyatakan berminat mendaftar pada prodi kewirausahaan.

\section{PENUTUP}

Simpulan

Berapa kesimpulan yang dapat ditarik dari hasil penelitian ini adalah sebagai berikut:

1. Minat studi lanjut siswa SMA/SMK Kota Bogor setelah lulus sekolah berada pada level sangat kuat (84,4\% memiliki minat untuk melanjutkan studi)

JAS-PT

JURNAL ANALISIS SISTEM PENDIDIKAN TINGG ISSN $2580-5339$ eISSN $2620-5718$

Volume 3

Nomor 1

JULI 2019

Hal $1-12$

FORUM DOSEN INDONESIA 
2. Tingkat minat studi lanjut siswa SMA/SMK Kota Bogor setelah lulus menunjukkan 51,5\% memiliki minat untuk melanjutkan studi sangat tinggi, 32,5\% memiliki minat tinggi/besar, $12,4 \%$ biasa saja dan 3,6\% sisanya tidak memberikan jawaban.

3. Jenjang pendidikan yang dipilih siswa siswi SMA/SMK di Kota Bogor setelah lulus adalah jenjang sarjana (84,28\%) dan jenjang pendidikan diploma tiga (10,84\%).

4. Jurusan/program studi yang dipilih untuk melanjutkan studi terbesr adalah pada jurusan ekonomi dan manajemen dengan prosentase sebesar $43,4 \%$ atau sebanyak 444 orang, diposisi kedua ditempati oleh program studi teknik yakni sebesar $19,1 \%$ atau 196 orang, posisi terrendah ditempati oleh program studi peternakan yang hanya sebesar $1,5 \%$ atau 15 dari 1024 orang yang disurvey.

5. Siswa yang merasa sangat yakin dengan pilihannya ada sebanyak $31,15 \%$, siswa yang menjawab yakin ada sebanyak $52,64 \%$, dengan demikian hasil olah data tersebut menunjukan bahwa siswa yang yakin dan sangat yakin terhadap pilihan program studi/jurusannya ada sebanyak $83,79 \%$ yang artinya bahwa kriteria interpretasi skor sangat kuat.

6. $45,80 \%$ Responden siswa SMA/SMK di Kota Bogor menyatakan pernah mendengar/tahu tentang prodi kewirausahaan, artinya prodi kewirausahaan sudah cukup dikenal di kalangan siswa SMA / SMK di Kota Bogor.

7. Responden siswa SMA/SMK di Kota Bogor yang menyatakan berminat untuk mendaftar pada prodi kewirausahaan hanya sebesar $15,23 \%$ artinya minat mendaftar pada prodi kewirausahaan masih relatif rendah.

\section{Saran}

Hasil Studi empiris masih menunjukkan bahwa Program Studi Kewirausahaan masih memegang peranan penting dalam pengembangan keilmuan dan penciptaan SDM yang memiliki karakter wirausaha yang dapat berkontribusi nyata terhadap pembangunan ekonomi. Perguruan Tinggi yang akan mengembangkan program studi Kewirausahaan harus ekstra dalam melakukan sosialisasi terhadap calon mahasiswanya sehingga terbentuk brand awareness yang nyata dan solid. Program perkuliahan yang handal dan memiliki outcome pada dunia industri dan dunia kerja harus menjadi target utama bagi Perguruan Tinggi dalam mengembangkannya, sehingga memberikan gambaran nyata kepada stakeholder akan pentingnya program studi kewirausahaan ini.

\section{DAFTAR PUSTAKA}

Ellitan, Lenna. (2001). "Strategi Mendongkrak Kualitas Pelayanan". Jurnal Ekonomi Sekolah Tinggi IImu Ekonomi Indonesia 15/Th. X.

Ghozali, Imam. (2005). Analisis Multi Variat dengan Program SPSS. Edisi Ketiga. Universitas Diponegoro, Semarang.

JAS-PT

JURNAL ANALISIS SISTEM PENDIDIKAN TINGG ISSN $2580-5339$ eISSN $2620-5718$

Volume 3

Nomor 1

JULI 2019

Hal $1-12$
Hidayat, L., Mulyana, M., \& Effendy, M. (2018). Membangun Kepuasan Mahasiswa Pengguna Laboratorium Komputer. JAS-PT Jurnal Analisis Sistem Pendidikan Tinggi, 1(2), 93-101.

Liang , Gie.1995. Cara Belajar Yang Efisien.Yogyakarta: Liberty

Mariyah, M. and Mulyana, M. (2015). ARTICLE REVIEW OF HUMAN CAPITAL, ECONOMIC STRUCTURE AND GROWTH. Jurnal Dosen STIE Kesatuan. 
Mulyana, M. (2012). Consumer Behaviour: Sukses Dengan Memahami Konsumen. ISBN 978-979-18531-6-3, Bogor: Kesatuan Press.

Mashadi, M., \& Irawan, R. (2017). Model Struktural Minat Mahasiswa Berkarir di Bidang Perbankan Syariah Sebagai Dasar Pengembangan Proses Pembelajaran. JASPT Jurnal Analisis Sistem Pendidikan Tinggi, 1(1), 1-10.

Mulyana, M. and Sulistiono, S. (2012). Kewirausahaan: The Long Life Way of Business.

Munandir. 1996. Program Bimbingan Karier di Sekolah. Jakarta: Direktur Jenderal Pendidikan Tinggi.

Nurendah, Y., Mulyana, M., \& Muanas, M. (2019). Evaluasi dan Pemetaan Minat Studi Siswa SMA dan SMK di Kota Bogor Pada Program Studi Ekonomi Syariah. JASPT Jurnal Analisis Sistem Pendidikan Tinggi, 2(2), 83 - 94.

Nurendah, Y. and Mulyana, M. (2013). Analisis Pengaruh Kualitas Pelayanan Perpustakaan Terhadap Kepuasan dan Hubungannya dengan Loyalitas Mahasiswa. Jurnal IImiah Manajemen Kesatuan, 1(1), pp.91-105.

Parasuraman, A. Zeithaml V.A. and Berry L.L. (1988). "A Multiple Item Scale for Measuring Consumer Perception of Service Quality". Journal of Retailling Vol. 64, spring: 12-14.

Sekaran, Uma. (2006). Metodologi Penelitian untuk Bisnis. Jilid Pertama. Edisi Keempat. Penerjemah Kwan Men Yon. Salemba Empat, Jakarta.

Walgito, Bimo. 2002. Pengantar Psikologi Umum. Yogyakarta: Andi Offset

Zimmerer, Thomas W. Norman, Scarborugh. (1996). Entrepreneurship The New Venture Forination. Prentice Hall International Inc. 
JAS-PT

JURNAL ANALISIS SISTEM PENDIDIKAN TINGGI

ISSN $2580-5339$

eISSN $2620-5718$

Volume 3

Nomor 1

JULI 2019

Hal 1 - 12

FORUM DOSEN INDONESIA 